\title{
Detection of humoral antibodies to Renibacterium salmoninarum in rainbow trout Oncorhynchus mykiss and Atlantic salmon Salmo salar challenged by immersion and in naturally infected populations
}

\author{
Eva Jansson ${ }^{1, *}$, Olle Ljungberg ${ }^{2}$ \\ ${ }^{1}$ National Veterinary Institute, Box 7073, S-750 07 Uppsala, Sweden \\ ${ }^{2}$ Department of Pathology, Faculty of Veterinary Medicine, Swedish University of Agricultural Sciences, Box 7028, \\ S-750 07 Uppsala, Sweden
}

\begin{abstract}
Humoral antibodies to heat-stable antigens of Renibacterium salmoninarum (Rs) were detected by enzyme-linked immunosorbent assay (ELISA) in rainbow trout Oncorhynchus mykiss and in Atlantic salmon Salmo salar challenged by immersion. A slow antibody response was found: $3 \%$ $(1 / 30)$ was positive $4 \mathrm{wk}$ after immersion and $72 \%(26 / 36)$ was positive after $8 w \mathrm{k}$. All 30 fish sampled after $4 \mathrm{wk}$ were found to be infected, as determined by bacterial culture and/or the presence of soluble antigens in the kidney. At 6,8 and $12 \mathrm{wk}$ after immersion the proportion of positives indicated by ELISA was $58 \%$. The Rs infection was detected by cultivation in $36 \%$ of sampled fish collected on the same occasion. Elevated antibody titres to Rs were detected in samples from both Atlantic salmon $159 \%$ in $1 \mathrm{farm})$ and from rainbow trout $(20 \%$ in 1 of 5 sampled farms) in naturally exposed populations all of which classified positive for bacterial kidney disease (BKD). Elevated antibody titres were detected among sampled fish from populations of rainbow trout and salmon with clinical BKD. Samples collected from farm populations of rainbow trout, salmon and brown trout Salmo trutta, exposed to Rs but without clinical BKD, were negative in the ELISA, although Rs bacteria or soluble antigens were detected at the same sampling. The antibody ELISA method cannot be recommended for general fish health monitoring purposes, but may be a valuable tool for monitoring the disease progression during controlled experiments.
\end{abstract}

KEY WORDS: Bacterial kidney disease Diagnostics - ELISA - Renibacterium salmoninarum Humoral antibodies

\section{INTRODUCTION}

Bacterial kidney disease (BKD) is caused by the slow-growing Renibacterium salmoninarum (Rs), and produces a chronic and systemic infection in salmonids (Fryer \& Sanders 1981). Health monitoring of farmed and feral fish populations and restrictions on movement of BKD-infected fish have been the most important methods for combatting BKD, as no effective chemotherapy or effective vaccine prophylaxis is available.

·E-mail: eva.jansson@sva.se
Immunological methods, such as immunofluorescence techniques, enzyme-linked immunosorbent assay (ELISA) and Western blot for detection of Rs antigens in internal organs, have been used as diagnostic tools (Bullock \& Stuckey 1975, Pascho \& Mulcahy 1987, Griffiths et al. 1991, Hsu et al. 1991, Gudmundsdottir et al. 1993, Olea et al. 1993, Jansson et al. 1996). Methods based on nucleic acid techniques have been developed for the detection of Rs in kidneys (Mattsson et al. 1993. León et al. 1994), in the ovarian fluid (Magnússon et al. 1994), and in salmonid eggs (Brown et al. 1994). These methods have improved the possibility of detecting BKD infections at an early stage, and thus reducing the 
risk of horizontal transmission. Vertically transferred infections might also be prevented by the detection of Rs in ovarian fluid and in eggs.

Several authors have reported the occurrence of antibodies to Rs antigens (Bartholomew et al. 1991, Griffiths et al. 1991) in serum from naturally infected salmonids such as chinook salmon Oncorhynchus tshawytscha and Atlantic salmon Salmo salar. The advantage of a serological method for the purpose of diagnosis would be that it is non-lethal and only a small amount of blood is necessary for the analysis. Bruno (1987) found agglutinating titres against Rs in sera to be an indication of infection in rainbow trout Oncorhynchus mykiss. He concluded, however, that this method was not reliable for Atlantic salmon populations, as no correlation between agglutinating titre and Rs infection in these populations occurred. To detect minor variations in antibody response and to trace a weak response, a more sensitive method would be of value. Olivier et al. (1992) detected Rs soluble antigen specific antibodies in Atlantic salmon by a modified Western blot, up to $141 \mathrm{~d}$ after intraperitoneal (i.p.) challenge at a temperature of $12^{\circ} \mathrm{C}$. However, this method was not found to be reliable for the identification of Rs-exposed salmon without clinical signs of BKD at temperatures below $8^{\circ} \mathrm{C}$ (Lovely et al. 1994). Sakai et al. (1991) developed a polyclonal ELISA for the detection of serum antibodies to Rs in coho salmon Oncorhynchus kisutch. A strong correlation between agglutinating antibody titres and the optical density (OD) values in ELISA was found. However, the specificity of the method was not evaluated.

Thuvander et al. (1990) showed that the monoclonal antibodies to rainbow trout immunoglobulin (IgM) are superior to polyclonals when applied in an ELISA for measuring fish antibodies to Vibrio anguillarum (Listonella anguillarum; MacDonell \& Colwell 1985) because they reduce background activity. We have used a monoclonal antibody in an ELISA for the detection of antibodies to heat-stable Rs antigens in Atlantic salmon, in brown trout Salmo trutta, and in rainbow trout. The ELISA technique was chosen for the serological studies as this is useful for routine screening of a large number of samples. The applicability of the ELISA method for monitoring the occurence of Rs infection in fish populations was evaluated in experimentally challenged Atlantic salmon and rainbow trout as well as in samples collected from fish at farms with enzootic BKD. The results of the ELISA for antibody detection were compared with the results of cultivation of Rs on agar and/or detection of soluble Rs antigens in kidneys by ELISA.

\section{MATERIALS AND METHODS}

Experimental infections and sampling. Rainbow trout and salmon were challenged by immersion for 30 min in oxygenated water containing Rs bacteria (Expts 1 to 4), summarized in Table 1. Fish in the control groups (111 rainbow trout and 54 salmon) were treated in the same way, but without the addition of bacteria to the water. The fish were observed daily. Surviving individuals were sampled, killed with an overdose of MS 222 (Sandoz, Ltd, Switzerland, $0.75 \mathrm{ml}$ $\left.\mathrm{l}^{-1}\right)$ and blood for antibody detection was collected from the caudal vessel: 6 and $12 \mathrm{wk}$ after challenge (Expt 1 and 2), 8 wk after challenge (Expt 3) and 4 and 8 wk after challenge (Expt 4). The blood was allowed to clot overnight at $4^{\circ} \mathrm{C}$ and centrifuged at $400 \times g$ for $10 \mathrm{~min}$. The sera were stored at $-20^{\circ} \mathrm{C}$ until tested. Dead and euthanized fish were gross-examined, and kidney samples were taken aseptically and placed into sterile bags for bacterial cultivation. In Expt 4 fish were sampled for soluble Rs antigens by ELISA. Fish in the control groups were sampled in the same manner.

Sampling in Rs-infected fish farms. Blood samples from a total of 380 fish were collected at 5 fish farms (Farms A to E) previously classified as Rs-infected since Rs had been isolated by bacterial cultivation:

Table 1. Summary of the experimental design of the 4 different infection experiments involving a challenge with Renibacterium salmoninarum (Rs) by immersion. The challenged fish were maintained in glass aquaria at a temperature of $13 \pm 2^{\circ} \mathrm{C}$ (Expts 1 to 3 ) or kept in tanks at a temperature of $14 \pm 2^{\circ} \mathrm{C}$ (Expt 4). Avg. wt: average weight at start of experiment. CFU: colony-forming units

\begin{tabular}{|c|c|c|c|c|c|c|}
\hline $\begin{array}{l}\text { Fish species } \\
\text { Expt no. }\end{array}$ & $\begin{array}{l}\text { Avg. wh } \\
(g)\end{array}$ & $\begin{array}{l}\text { Bacterial } \\
\text { strain }\end{array}$ & $\begin{array}{c}\text { Dose of } \\
\text { infecting Rs } \\
\text { (CFU ml-1 water) }\end{array}$ & $\begin{array}{l}\text { No. of fish } \\
\text { challenged }\end{array}$ & $\begin{array}{l}\text { No. of dead or } \\
\text { moribund fish }\end{array}$ & $\begin{array}{l}\text { No. of fish killed } \\
\text { for sampling } \\
\text { (wk after challenge) }\end{array}$ \\
\hline \multicolumn{7}{|l|}{ Rainbow trout } \\
\hline Expt 1 & 30 & Rs $4 / 86$ & $5 \times 10^{7}$ & 18 & 4 & $14 \quad(6$ and 12$)$ \\
\hline Expt 2 & 20 & Rs 4/86 & $5 \times 10^{7}$ & 40 & 0 & (6 and 12) \\
\hline Expt 3 & 30 & Rs 4/86 & $4 \times 10^{8}$ & 20 & 7 & (8) \\
\hline Expt 4a & 32 & Rs $15 / 67 / 92$ & $1 \times 10^{8}$ & 70 & 31 & 39 (4 and 8$)$ \\
\hline \multicolumn{7}{|l|}{ Atlantic salmon } \\
\hline Expt $4 \mathrm{~b}$ & 35 & Rs $15 / 67 / 92$ & $1 \times 10^{8}$ & 70 & 42 & 28 (4 and 8$)$ \\
\hline
\end{tabular}


328 samples originated from rainbow trout, 29 from Atlantic salmon, and 23 from brown trout. The fish were examined for macroscopic lesions indicative of $B K D$, and kidney samples were taken aseptically and placed into sterile bags for bacterial cultivation (Farms $A$ to $D$ ) or for detection of soluble Rs antigens by ELISA (Farm E)

Bacterial cultivation. The kidney samples were mechanically homogenized (Stomacher Lab Blender 80, Seward Laboratory, UK) in peptone-saline (P-S; $0.1 \%$ peptone, Difco, USA; $0.9 \% \mathrm{NaCl}$ ), approximately $10 \mathrm{ml} \mathrm{g}^{-1}$ of tissue, and centrifuged at $2500 \times \mathrm{g}$ at $4^{\circ} \mathrm{C}$. Supernatants were discarded and the pellets were resuspended in P-S at a 1:1 ratio. Ten microlitres of the homogenate was spread on selective kidney disease medium (SKDM), supplemented with 10\% heatinactivated sheep serum instead of calf serum, as originally described (Austin et al. 1983). Agar plates were incubated at $15^{\circ} \mathrm{C}$ and examined weekly up to 12 wk. Growth of Rs was confirmed by Gram staining and an immunofluorescense technique using a monoclonal antibody to Rs (Micrologix Intenational Limited, Canada) on typical colonies from SKDM agar.

ELISA for the detection of soluble Rs antigens. Soluble Rs antigens were detected by the ELISA performed as previously described (Jansson et al. 1996). Kidney samples were prepared with $0.01 \mathrm{M}$ phosphatebuffered saline pH 7.4 (PBS) and the solvent HemoDe (Fisher Scientific, USA) in a stomacher and heated to $98 \pm 2^{\circ} \mathrm{C}$ in an autoclave. The aqueous phase was collected after centrifugation and analysed by the ELISA. In some cases preparations were stored at $-20^{\circ} \mathrm{C}$ until tested. All incubations were performed at $24^{\circ} \mathrm{C}$.

ELISA for the detection of humoral antibodies. The Rs strain 4/86 (National Veterinary Institute, Sweden) was inoculated into $190 \mathrm{ml}$ of semidefined medium (Embley et al. 1982) and incubated with agitation at $17^{\circ} \mathrm{C}$ for $2 \mathrm{wk}$ to an $O D$ of 2.1 at $578 \mathrm{~nm}$. Bacterial growth was harvested and washed 2 times in PBS. The pellet was resuspended in $10 \mathrm{ml} \mathrm{PBS}$ and heated to $100 \pm 2^{\circ} \mathrm{C}$ in an autoclave for $15 \mathrm{~min}$. Microtitre plates (Nunc, Denmark) were coated overnight with the heatkilled Rs preparation diluted 1:400 in $0.05 \mathrm{M}$ carbonate buffer, pH 9.6 (200 $\mu$ l well $\left.{ }^{-1}\right)$ and then washed 3 times in saline $(0.9 \% \mathrm{NaCl} ; 0.001 \mathrm{M}$ PBS) containing $0.5 \%$ Tween 20. Subsequently fish serum, diluted 1:100 (Thuvander et al. 1987) in PBS containing $0.5 \%$ Tween (PBS-T), was added to duplicate wells $\left(100 \mu l\right.$ well $\left.^{-1}\right)$ and the plates were incubated overnight at $15^{\circ} \mathrm{C}$. After washing 3 times as described above, a mouse monoclonal antibody (Clone 4c10:3) to salmonid IgM (Thuvander et al. 1990), diluted 1:100 in PBS-T, was added to each well $\left(100 \mu \mathrm{l} \mathrm{well}^{-1}\right)$. The plates were incubated for $2 \mathrm{~h}$ at $37^{\circ} \mathrm{C}$ and then washed. Rabbit anti-mouse immunoglobulins conjugated with peroxidase (DAKO
AS, Denmark) were added (100 $\mu$ well $\left.^{-1}\right)$ followed by a $1 \mathrm{~h}$ incubation at $37^{\circ} \mathrm{C}$. Finally the enzyme reaction was visualized using $0.1 \mathrm{mg} \mathrm{ml}^{-1}$ of tetramethylbenzidine (Kebo, Sweden) in $0.1 \mathrm{M}$ acetate buffer, $\mathrm{pH} 6.0$, containing $0.006 \% \mathrm{H}_{2} \mathrm{O}_{2}$. The reaction was stopped after 10 min with $50 \mu \mathrm{ll} \mathrm{M} \mathrm{H}_{2} \mathrm{SO}_{4}$ and the OD was measured in a spectrophotometer at $450 \mathrm{~nm}$.

Fish samples showing OD values higher than the mean value plus 3 standard deviations of the nonchallenged fish (in each experiment) were considered to be seropositive. The negative-positive threshold value $(0.341)$ of samples collected from Farms $A$ to $E$ was based on the mean value plus 3 standard deviations of the non-challenged fish $(n=154)$ in all experiments.

Statistical analysis. OD values from the ELISA for antibody detection were analysed for statistically significant differences between non-infected and Rs-infected groups by a Wilcoxon rank sum test. The agreement between cultivation on SKDM and detection of antibodies to heat-stable Rs antigens for the diagnosis of BKD was estimated by the kappa statistic and its $95 \%$ confidence interval (CI) (Fleiss 1981). Association between OD values in ELISA, for the measure of soluble Rs antigens detected in kidneys an the amount of Rs antibodies in serum was estimated by correlation.

\section{RESULTS}

\section{Experimental infection}

BKD was induced by immersion of rainbow trout and salmon in the experimental infections (Expts 1 to 4). Characteristic BKD lesions, such as greyish-white swollen kidneys, were recorded in fish that died from the disease and also from euthanized fish. Rs was isolated and soluble Rs antigens detected from examined kidneys of already dead and killed fish with clinical signs of $\mathrm{BKD}$, but Rs was also isolated from $38 \%$ of killed fish without any indications of disease at necropsy. Soluble Rs antigens were detected in $98 \%$ of the challenged fish without signs of disease in Expt 4.

\section{ELISA for the detection of humoral antibodies}

Humoral antibodies to heat-treated Rs were determined in the experimentally challenged fish 4, 6, 8 and 12 wk after immersion (Fig. 1). One fish out of 30 was seropositive when sampled 4 wk after challenge, although Rs was cultivated from the kidneys and/or soluble Rs antigens detected in all 30 fish sampled at the same time. A peak in the proportion of seropositives was found at Week 8 after challenge when 35 of 

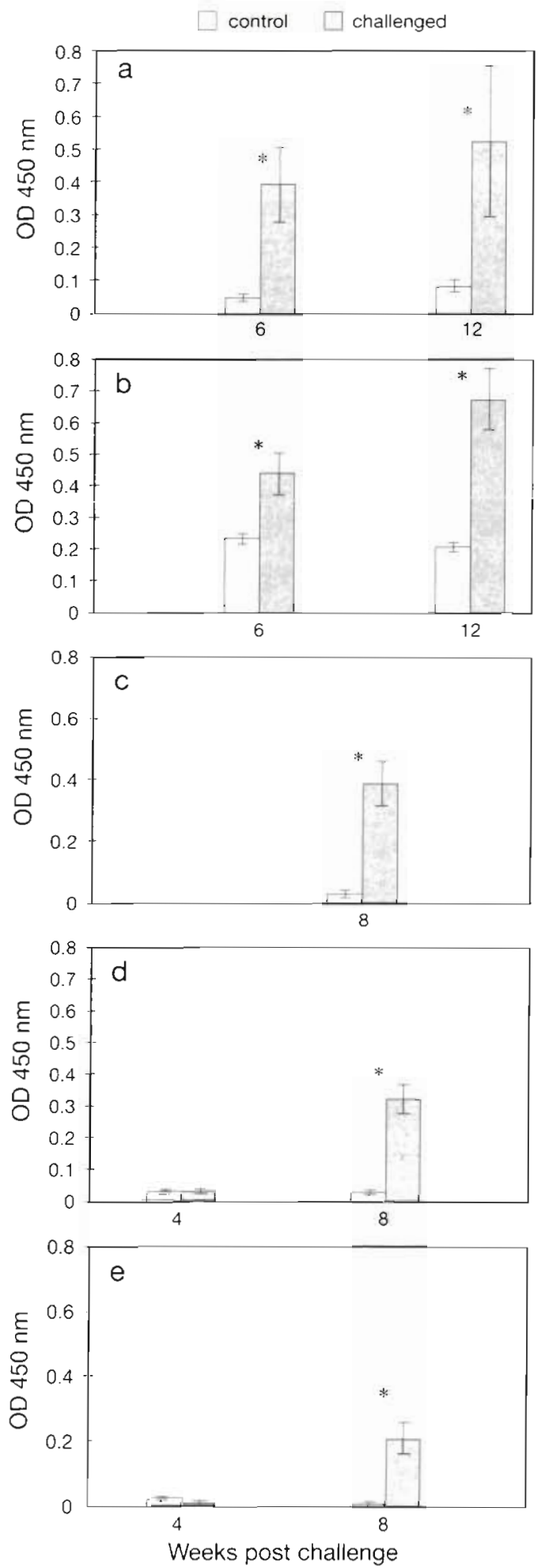

Fig 1. Oncorhynchus mykiss and Salmo salar. Humoral antibody levels, expressed as mean optical density (OD) 450 values $( \pm \mathrm{SE})$, to heat-stable antigens from Renibacterium salmoninarum. Results from experimentally infected rainbow trout: (a) Expt 1, (b) Expt 2, (c) Expt 3, (d) Expt 4a; and from Atlantic salmon: (e) Expt 4 b. * Significantly $(p<0.05)$ different from control (non-challenged) fish
49 were seropositive (Fig. 2). Rs was cultivated from $36 \%$ of fish sampled 6,8 and 12 wk after challenge, compared with $58 \%$ on the samc occasion which were classified as positive by detection of Rs antibodies by ELISA (Table 2). No positives were detected in the non-infected rainbow trout $(\mathrm{n}=108$ ), but sera from 3 non-infected salmon ( $\mathrm{n}=48$ ) showed elevated $\mathrm{OD}$ values. Fair agreement between cultivation on SKDM and antibody detection by ELISA was found in the samplings 6,8 and $12 \mathrm{wk}$ after challenge, with a kappa value of $0.33(95 \% \mathrm{CI}, 0.13$ to 0.54$)$ when samples with an overgrowth of contaminating microbes on SKDM were excluded from the calculations. No correlation was found between the soluble Rs antigens detected in kidneys and the amount of Rs antibodies (comparison of $O D$ values) in Expt 4.

A high proportion of seropositive fish was detected in salmon at Farm A during an acute outbreak of BKD at the end of June involving a mortality of $30 \%$. No indications of BKD were found in rainbow trout at the same farm, either by gross examination or cultivation, or by analysis of sera for Rs antibodies during sampling in June to November. At farm B, humoral antibodies to Rs were detected in rainbow trout with macroscopic BKD lesions, but only in 2 of 10 fish. Farms $C$ to $E$ showed a low prevalence of $\mathrm{BKD}$ and only a single seropositive fish was found in these farms when sampled during the period from November to the beginning of June (Table 3). Only 1 population with brown trout $(\mathrm{n}=23)$ was tested in this study (Farm E), without any clinical indications of BKD. All sampled brown trout were seronegative and no soluble Rs antigens were detected in the kidneys.

\section{DISCUSSION}

Challenge by injection is the most widely used experimental method in BKD studies. This challenge

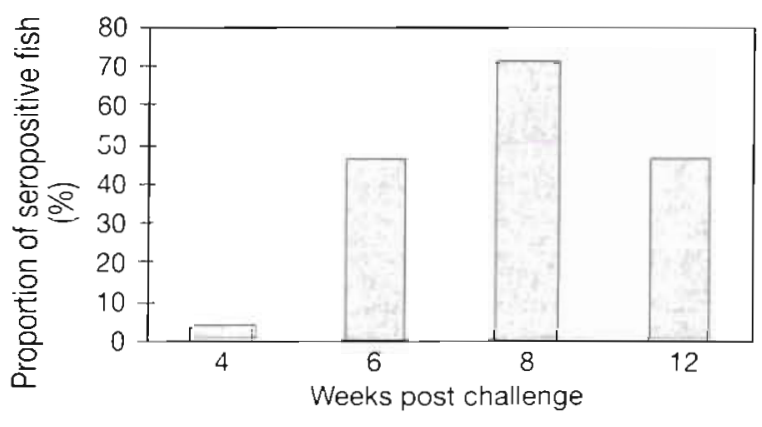

Fig. 2. Oncorhynchus mykiss and Salmo salar. Proportion of seropositive fish, after challenge in water containing Renibacterium salmoninarum (Expts 1 to 4). Results include sampling at $4(n=30), 6(n=26), 8(n=49)$ and $12(n=28) w k$ after immersion 
Table 2. Isolation of Renibacterium salmoninarum (Rs), detection of soluble Rs antigens in kidney and detection of humoral antibodies to heat-stable antigens of Rs by enzyme-linked immuosorbent assay (ELISA) in rainbow trout and salmon experimentally challenged with Rs by immersion. SKDM: selective kidney disease medium; +: no. positive

\begin{tabular}{|c|c|c|c|c|c|}
\hline $\begin{array}{l}\text { Fish species } \\
\text { Expt no. }\end{array}$ & $\begin{array}{l}\text { Sampling } \\
\text { (wk after immersion) }\end{array}$ & $n$ & $\begin{array}{l}\text { Rs isolated from } \\
\text { kidney on SKDM } \\
\text { (+/total tested) }\end{array}$ & $\begin{array}{c}\text { Soluble Rs antigens detected } \\
\text { in kidney by ELISA } \\
\text { (+/total tested) }\end{array}$ & $\begin{array}{l}\text { Humoral antibodies } \\
\text { detected by ELISA } \\
\text { (+/total tested })\end{array}$ \\
\hline \multicolumn{6}{|c|}{ Rainbow trout } \\
\hline \multirow[t]{2}{*}{ Expt 1} & 6 & 6 & $3 / 6$ & Not tested & $6 / 6$ \\
\hline & 12 & 8 & $1 / 8$ & Not tested & $3 / 8$ \\
\hline \multirow[t]{2}{*}{ Expt 2} & 6 & 20 & $5 / 20$ & Not tested & $6 / 20$ \\
\hline & 12 & 20 & $5 / 20$ & Not tested & $10 / 20$ \\
\hline Expt 3 & 8 & 13 & $10 / 13$ & Not tested & $9 / 13$ \\
\hline \multirow[t]{2}{*}{ Expt $4 \mathrm{a}$} & 4 & 22 & $18 / 22$ & $23 / 23$ & $1 / 23$ \\
\hline & 8 & 16 & $6 / 16$ & $16 / 16$ & $13 / 16$ \\
\hline \multicolumn{6}{|c|}{ Atlantic salmon } \\
\hline \multirow[t]{2}{*}{ Expt 4b } & 4 & 7 & $6 / 7$ & $7 / 7$ & $0 / 7$ \\
\hline & 8 & 21 & $7 / 21$ & $20 / 21$ & $13 / 20$ \\
\hline
\end{tabular}

method, however, bypasses the natural skin and mucous barriers of the fish. We have chosen to use immersion of the fish in water contaminated with live bacteria, in order to mimic the natural mode of disease transmission, pathogenesis, and activation of the immune response. Elevated levels of antibodies to Rs in this study were demonstrated after experimental infection in both rainbow trout and salmon. This study does not indicate any differences between the 2 species in their ability to mount an antibody response against Rs, although differences in susceptibility to BKD has been demonstrated (Starliper et al. 1997). The antibody response developed slowly as only 1 sero- positive fish out of 30 was detected 4 wk after immersion and $72 \%(26 / 36)$ was positive after $8 \mathrm{wk}($ Expt 4$)$ even though the temperature $\left(14 \pm 2^{\circ} \mathrm{C}\right)$ was considered to be optimal for outbreaks of the disease and also sufficient for the production of antibodies. The slow response agrees with the results of Evelyn (1971) in sockeye salmon Oncorhynchus nerka. The highest proportion of seropositive fish in our study was found $8 \mathrm{wk}$ after immersion. A wide range of OD values was seen in challenged fish in all experiments and the highest individual value $\left(\mathrm{OD}_{450}=1.788\right)$ was obtained $12 \mathrm{wk}$ after challenge. Olivier et al. (1992) detected antibodies to soluble Rs antigens up to $20 \mathrm{wk}$ after

Table 3. Isolation of Renibacterium salmoninarum (Rs), detection of soluble Rs antigens by ELISA from kidneys and detection of humoral antibodies to heat-stable antigens of Rs in fish farms with varying prevalence of bacterial kidney disease (BKD) (BKD earlicr diagnosed by cultivation of Rs from kidney samples from all farms). Farm A: $80 \%$ of examined salmon showed macroscopic lesions indicative of BKD when sampled in June. No indications of BKD, either by gross examination or by cultivation on SKDM, were found in sampled rainbow trout. Farm B: $50 \%$ of sampled rainbow trout showed macroscopic lesions indicative of BKD at autopsy. Farm C and D: Only a small number of fish with lesions indicative of BKD. Farm E: No fish with lesions indicative of $\mathrm{BKD}$. + no. positive

\begin{tabular}{|c|c|c|c|c|c|}
\hline Farm & Month & Fish species & $\begin{array}{l}\text { Rs isolated from kidney } \\
\qquad(+/ \text { total tested })\end{array}$ & $\begin{array}{c}\text { Soluble Rs antigens } \\
\text { detected by ELISA } \\
\text { (+/total tested) }\end{array}$ & $\begin{array}{l}\text { Humoral antibodies } \\
\text { detected by ElISA } \\
(+/ \text { total tested })\end{array}$ \\
\hline A & $\begin{array}{l}\text { June } \\
\text { October } \\
\text { November }\end{array}$ & $\begin{array}{l}\text { Salmon } \\
\text { Rainbow trout } \\
\text { Rainbow trout } \\
\text { Rainbow trout }\end{array}$ & $\begin{array}{l}8 / 50^{a} \\
0 / 19^{d} \\
0 / 52 \\
0 / 60\end{array}$ & $\begin{array}{l}\text { Not tested } \\
\text { Not tested } \\
\text { Not tested } \\
\text { Not tested }\end{array}$ & $\begin{array}{r}17 / 29 \\
0 / 46 \\
0 / 52 \\
0 / 60\end{array}$ \\
\hline B & November & Rainbow trout & $4 / 5^{d}$ & Not tested & $2 / 10$ \\
\hline C & November & Rainbow trout & $1 / 17^{\circ}$ & Not tested & $1 / 30$ \\
\hline D & April & Rainbow trout & $4 / 60$ & Not tested & $0 / 60$ \\
\hline$E$ & June & $\begin{array}{l}\text { Rainbow trout } \\
\text { Brown trout }\end{array}$ & $\begin{array}{l}\text { Not tested } \\
\text { Not tested }\end{array}$ & $\begin{array}{l}3 / 86 \\
0 / 24\end{array}$ & $\begin{array}{l}0 / 70 \\
0 / 23\end{array}$ \\
\hline
\end{tabular}


challenge without any evidence for the presence of Rs either by culture or by detection of Rs antigens. A higher sensitivity of the ELISA for the detection of humoral antibodies compared with cultivation on SKDM was also indicated in this study in the sampling 6,8 and $12 \mathrm{wk}$ after challenge. It is possible that elevated antibody levels, at times, might be a better indication of exposure to Rs in a fish population than Rs bacterial cultivation. Inter-rater agreement on the kappa statistic of individual samples showed a fair agreement between the 2 methods, which demonstrates that antibody detection could only be used for assessing exposure at the population level, and not for the identification of individual fish. Dixon (1996) found detection of specific rainbow trout antibodies by ELISA to be a suitable method for identiifying fish populations that had been exposed to infectious pancreatic necrosis virus, but not for the assessment of individual fish. Thorburn \& Jansson (1988) also found individual seronegative rainbow trout after i.p. vaccination against vibriosis.

OD values below the negative-positive threshold value in the challenged groups sampled 6 to $12 \mathrm{wk}$ after exposure (Table 2) may reflect a weak immune response in individual fish. However, they may also be explained by bacterial destruction of tissues important for antibody formation. Turaga et al. (1987) showed that soluble antigens produced by Rs suppressed the antibody response in vitro of coho salmon lymphocytes. Paterson et al. (1981) suggested that absence of agglutinating antibodies in Atlantic salmon after injection of killed Rs was due to a low antigenicity of Rs in comparison to other fish pathogenic bacteria.

Bartholomew et al. (1991) found a similar pattern of Rs antigens recognized by serum from. chinook salmon and rabbits immunized with Rs cells in Western blot analysis, indicating a specific immune response. Olivier et al. (1992) found that sera from 2 salmon contained immunoglobulin reactive with the major $57 \mathrm{kDa}$ soluble Rs antigen a few days after i.p. injection by the modified Western blot. We found 3 out of 52 salmon with elevated $O D$ values in the non-infected groups. This result was unexpected as there were no indications of BKD in the farm of origin during regular health monitoring over a period of several years. No growth of bacteria was detected when kidney samples from these fish were cultivated on SKDM. This result indicates that the specificity of the antibody response to Rs must be investigated more carefully before the method can be recommended for use in screening programs.

Rs seropositive salmon and rainbow trout were detected in fish sampled in farms with clinical BKD. Sensitive methods such as the ELISA technique and Western blot are of value for the detection of a weak antibody response. Antibody production and the anti- body levels in the fish will be related to ambient water parameters which ought to be taken into consideration if specific antibody detection is used for disease screening purposes. Low water temperatures (below $8^{\circ} \mathrm{C}$ ) the weeks previous to sampling is a reasonable explanation for the few seropositive fish detected in Farms B to E (Table 3), which in agreement with the results of Lovely et al (1994).

The long induction time required for the appearance of detectable antibodies and the abscence of seropositive fish among exposed, asymptomatic carriers, demonstrates that serological methods cannot be recommended alone in fish health screening programs. However, the antibody ELISA method may be a valuable complement to other techniques under controlled experımental conditions, for example, for monitoring valuable stocks already known to be BKD infected, and for developing vaccinations which allow blood samples to be analysed without first killing the fish.

Acknowledgements. We thank Dr Ann Thuvander for the gift of the monoclonal antibodies against salmonid IgM and UlfPeter Wichardt and Anders Alfjorden from The Swedish Fish Health Control Programme for their help with the sample collection. We also thank Jane Fasten and Ola Sundgren for their skilful technical assistance and finally Dr Lars Pilström and Dr Bengt Larsson for valuable comments on this manuscript. This work was supported by the Nordic Council of Ministers and the Swedish Council. for Forestry and Agricultural Research.

\section{LITERATURE CITED}

Austin B, Embley TM, Goodfellow M (1983) Selective isolation of Renibacterium salmoninarum. FEMS Microbiol Lett 17:111-114

Bartholomew JL, Arkoosh MR, Rohovec JS (1991) Demonstration of the specificity of the salmonid humoral response to Renibacterium salmoninarum with a monoclonal antibody against salmonid immunoglobulin. J Aquat Anim Health $3: 254-259$

Brown LL, Iwama GK, Evelyn TPT, Nelson WS, Levine RP (1994) Use of the polymerase chain reaction (PCR) to detect DNA from Renibacterium salmoninarum within individual salmonid eggs. Dis Aquat Org 18:165-171

Bruno DW (1987) Serum agglutinating titres against Renibacterium salmoninarum the causative agent of bacterial kidney disease, in rainbow trout, Salmo gairdneri Richardson, and Atlantic salmon, Salmo salar L. J Fish Biol 30: $327-334$

Bullock GL, Stuckey HM (1975) Fluorescent antibody identification and detection of the Corynebacterium causing kidney disease of salmonids. J Fish Res Bd Can 32: $2224-2227$

Dixon PF (1996) Use of antibody screening for the identification of rainbow trout carriers of infectious pancreatic necrosis virus in a broodstock management scheme: preliminary study. Bull Eur Assoc Fish Pathol 16:125-128

Embley TM, Goodfellow M, Austin B (1982) A semi-defined growth medium for Renibacterium salmoninarum. FEMS Microbiol Lett 14:299-301

Evelyn TPT (1971) The agglutinin response in sockeye 
salmon vaccinated intraperitoneally with a heat-killed preparation of the bacterium responsible for salmonid kidney disease. J Wild? Dis 7:328-335

Fleiss JL (1981). Statistical methods for rates and proportions, 2nd edn. John Wiley \& Sons, New York, p 212-233

Fryer JL, Sanders JE (1981) Bacterial kidney disease of salmonid fish. Annu Rev Microbiol 35:273-298

Griffiths SG, Olivier G, Fildes J, Lynch WH (1991) Comparison of Western blot, direct fluorescent antibody and dropplate culture methods for the detection of Renibacterium salmoninarum in Atlantic salmon (Salmo salar L.). Aquaculture 97:117-129

Gudmundsdottir S, Benediktsdottir E, Helgason S (1993) Detection of Renibacterium salmoninarum in salmonid kidney samples: a comparison of results using doublesandwich ELISA and isolation on selective medium. J Fish Dis 16:185-195

Hsu H, Bowser PR, Schachte JH (1991) Development and evaluation of a monoclonal-antibody-based enzymelinked immunosorbent assay for the diagnosis of Renibacterium salmoninarum infection. J Aquat Anim Health 3: $168-175$

Jansson E, Hongslo T, Höglund J, Ljungberg O (1996) Comparative evaluation of bacterial culture and two ELISA techniques for the detection of Renibacterium salmoninarum antigens in salmonid kidney tissues. Dis Aquat Org $27: 197-206$

León G, Maulén N, Figueroa J, Villanueva J, Rodríguez C, Vera Ml, Krauskopf M (1994) A PCR-based assay for the identification of the fish pathogen Renibacterium salmoninarum. FEMS Microbiol Lett 115:131-136

Lovely JE, Cabo C, Griffiths SG, Lynch WH (1994) Detection of Renibacterium salmoninarum in asymptomatic Atlantic salmon. J Aquat Anim Health 6:126-132

MacDonell MT, Colwell RR (1985) Phylogeny of the Vibrionaceae, and recommendation for two new genera, Listonella and Shewanella. Syst Appl Microbiol 6:171-182

Magnússon $\mathrm{HB}$. Fridjónsson $\mathrm{OH}$, Andrésson OS, Benediktsdóttir E, Gudmundsdóttir S, Andresdóttir V (1994) Renibacterium salmoninarum, the causative agent of bacterial kidney disease in salmonid fish, detected by nested reverse transcription-PCR of 16S rRNA sequences. Appl Environ Microbiol 60:4580-4583

Mattsson JG, Gersdorf H, Jansson E, Hongslo T, Göbel UB,

Editorial responsibility: David Bruno,

Aberdeen, Scotland UK
Johansson KE (1993) Rapid identification of Renibacterium salmoninarum using an oligonucleotide probe complementary to 16S rRNA. Mol Cell Probes 7:25-33

Olea 1, Bruno DW, Hastings TS (1993) Detection of Renibact'rum salmoninarum in naturally infected Atlantic salmon, Salmo salar L., and rainbow trout. Oncorhynchus mykiss ( $W_{\mathrm{c}} \mathrm{lb}_{\mathrm{a} u m}$ ) using an enzyme-linked immunosorbent assay. Aquaculture 116:99-110

Olivinr G, Griffiths SG, Fildes J, Lynch WH (1992) The use of Wostern blot and electroimmunotransfer blot assays to monitor bacterlal kidney disease in experimentally challenged Atlantic salmon, Salmo salar L. J Fish Dis 15 : $229-241$

Pascho RJ, Mulcahy D (1987) Enzyme-linked immunosorbent assay for a soluble antigen of Renibacterium salmoninarum, the causative agent of salmonid bacterial disease. Can J Fish Aquat Sci 44:183-191

Paterson WD, Desautels D, Weber JM (1981) The immune response of Atlantic salmon, Salmo salar L., to the causative agent of bacterial kidney disease, Renibacterium salmoninarum. J Fish Dis 4:99-111

Sakai M. Atsuta S, Kobatashi M (1991) The detection of serum antibody to Renibacterium salmoninarum in pen-cultured cohosalmon, Oncorhynchus kisutch (Walbaum). J Fish Dis $14: 243-246$

Starliper C, Smith D, Shatzer T (1997) Virulence of Renibacterium salmoninarum to salmonids. J Aquat Anim Health 9:1-7

Thorburn $M$, Jansson $E$ (1988) Frequency distributions in rainbow trout populations of absorbance values from an ELISA for Vibrio angullarum antibodies. Dis Aquat Org $5: 171-177$

Thuvander A, Fossum C, Lorenzen N (1990) Monoclonal antibodies to salmonid immunoglobulin: characterization and applicability in immunoassays. Dev Comp Immunol $14: 415-423$

Thuvander A, Hongslo T, Jansson E, Sundquist B (1987) Duration of protective immunity and antibody titres measured by ELISA after vaccination of rainbow trout, Salmo gairdneri Richardson, against vibriosis. J Fish Dis 10: $479-486$

Turaga P, Wiens G, Kaattari S (1987) Bacterial kidney disease: the potential role of soluble protein antigen(s). J Fish Biol 31:191-194

Submitted: October 17, 1997; Accepted: April 7, 1998

Proofs received from author(s): June 10, 1998 